\title{
Mesin Pencacah Daun dan Pelepah Kelapa Sawit Untuk Peternak Sapi di Desa Pancar Gading Kecamatan Tapung Kabupaten Kampar - Riau
}

\author{
Latifa Siswati ${ }^{1}$, Anto Ariyanto ${ }^{2}$, David Setiawan*3, Jeni Wardi ${ }^{4}$, Alexander Yandra ${ }^{5}$ \\ 1,2Program Studi Agribisnis, Fakultas Pertanian, Universitas Lancang Kuning \\ 3Program Studi Teknik Elektro, Fakultas Teknik, Universitas Lancang Kuning \\ 4Program Studi Akuntansi, Fakultas Ekonomi, Universitas Lancang Kuning \\ ${ }^{5}$ Program Studi Ilmu Administrasi Negara, Fakultas Ilmu Administrasi, Universitas Lancang Kuning \\ *e-mail : dsetia@unilak.ac.id ${ }^{3}$
}

\begin{abstract}
Animal feed such as cattle is not only made from grass, animal feed can also be produced from palm leaves. The vast area of oil palm plantations in Riau in general and in Kampar in particular, has not been used optimally for animal feed. The Merpati Putih Foundation, which is located in Pancar Gading Village, Tapung District, Kampar Regency, Riau, has 600 cattle. Cattle feed is received by farmers from farmers who weed every day, but the feed collected by farmers always does not meet the required cattle feed, so a solution to this problem is needed. The service activity carried out is to provide a solution in the form of a feed chopper machine that can chop palm leaves and sheaths into animal feed so that the need for animal feed is no longer a problem. To meet the required animal feed, a chopper machine with a large capacity is needed. The chopper that will be provided is made with a capacity of 4,000 to 5,000 kg per hour where the feed chopper uses a Mitsubishi PS 100 engine, which is a machine that is durable and easy to maintain. The chopping machine will be used by two partners at once, namely farmers as suppliers of animal feed and farmers as cattle owners. From the results of the activities carried out, it is hoped that farmers and ranchers will get an increase in their respective production results, namely adequate feed with easily obtained raw materials, namely abundant palm oil and for farmers, namely fat and healthy cows so that they get a high selling price.
\end{abstract}

Keywords: Enumeration Machine, Animal Feed, Breeder, Cow, Kampar.

\begin{abstract}
Abstrak
Pakan ternak seperti sapi tidak saja dari rumput, pakan ternakjuga dapat dihasilkan dari daun sawit. Luasnya area perkebunan sawit di Riau secara umum dan di Kampar secara khusus, belum dimanfaatkan secara optimal untuk pakan ternak. Yayasan Merpati Putih yang berada di Desa Pancar Gading Kecamatan Tapung Kabupaten Kampar, Riau memiliki 600 an ternak sapi. Pakan sapi diterima peternak dari petani yang menyiang rumput setiap harinya, namun pakan yang dikumpulkan petani selalu saja belum memenuhi pakan ternak sapi yang dibutuhkan, sehingga perlu solusi dari permasalahan tersebut. Kegiatan pengabdian yang dilakukan adalah memberikan solusi yaitu berupa mesin pencacah pakan yang dapat mencacah daun dan pelapah sawit menjadi pakan ternak sehingga kebutuhan pakan ternak tidak lagi menjadi masalah. Untuk memenuhi pakan ternah yang dibutuhkan maka dibutuhkan mesin pencacah dengan kapasitas yang besar. Mesin pencacah yang akan diberikan dibuat dengan kapasitas 4.000 sampai dengan $5.000 \mathrm{~kg}$ per jam dimana mesin pencacah pakan tersebut menggunakan mesin mitsubishi PS 100 yaitu mesin yang awet dan mudah perawatannya. Mesin pencacah akan dimanfaatkan oleh dua mitra sekaligus yaitu petani sebagai pemasok pakan ternak dan peternak sebagai pemilik sapi. Dari hasil kegiatan yang dilakukan, diharapkan petani dan peternak mendapatkan peningkatan hasil produksinya masing - masing yaitu pakan yang berkecukupan dengan bahan baku yang mudah diperoleh yaitu sawit yang berlimpah dan bagi peternak yaitu sapi yang gemuk dan sehat sehingga mendapatkan harga jual yang tinggi.
\end{abstract}

Kata kunci: Mesin Pencacah, Pakan Ternak, Peternak, Sapi, Kampar.

\section{PENDAHULUAN}

Desa Pancar Gading Kecamatan Tapung memiliki Yayasan merpati putih yang memelihara ternak sapi sebanyak 497 ekor dengan kebutuhan pakan sapi sekitar $1988 \mathrm{~kg}$ hijuan pakan ternak setiap hari. Kebutuhan pakan ternak tersebut tidak dapat dipenuhi hanya mengandalkan rumput alam,Jerami padi dan limbah tanaman jagung. Ternak sapi merupakan aktfitas yang sangat potensial kedepan tentu dengan menyesuakan dengan perkembangan yang ada sekarang akan 
mengefisiensi pengeluaran petani (Latifa: 2021). Di Desa Pancar Gading Kecamatan Tapung banyak kebun kelapa sawit yang dapat dimanfaatkan sebagai sumber pakan bagi ternak sapi. Selama ini belum memanfaatkan limbah daun kelapa sawit untuk pakan ternak juga belum memiliki mesin pencacah pakan . dengan alat pencacah daun dan pelepah sawit dapat membantu memenuhi kebutuhan pakan ternak sapi , jika kebutuhan pakan terdak terpenuhi maka pertumbuhan sapi tidak optimal. Sapi merupakan sumber daging bagi masyarakat pada saat tertentu permintaan sapi meningkat saat hari raya idul adha,idul fitri yang Sebagian besar masyarakat pada idul adha membutuhkan lebih banyak sapi untuk qurban.

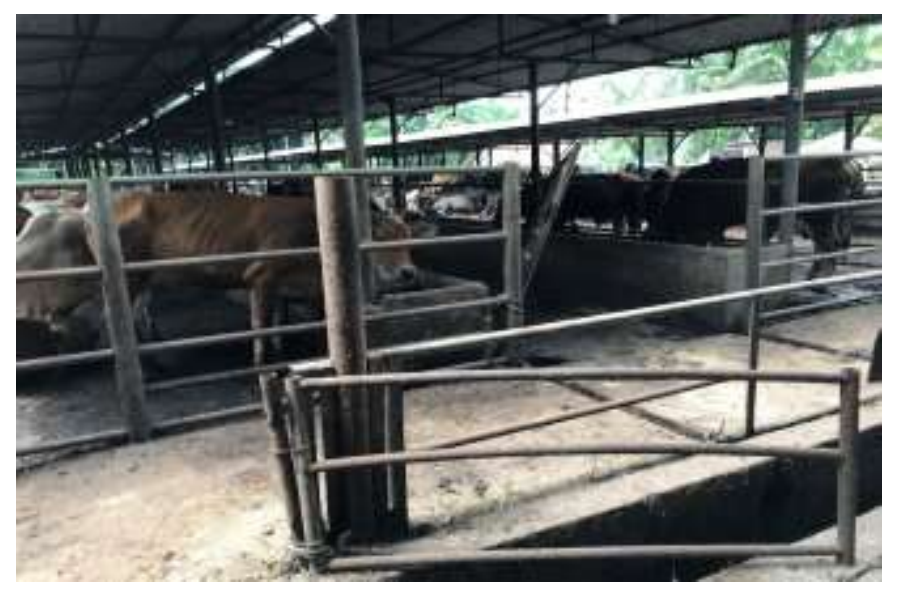

Gambar 1. Ternak Sapi Yayasan Merpati Putih Kampar

Hasil rapat dan survei wilayah, peternak sapi di Kabupaten Kampar khususnya di Desa Pancar Gading Kecamatan Tapung juga memiliki perkebunan kelapa sawit. Dalam proses pemeliharaan kebun kelapa sawit, selain proses pemupukan untuk meningkatkan pertumbuhan batang dan produksi buah kelapa sawit, proses lain yang dilakukan adalah pemotongan pelepah bawah kelapa sawit pada umur tertentu yang bertujuan untuk merangsang pertumbuhan batang kelapa sawit. menjadi lebih besar. dibuang begitu saja tanpa dimanfaatkan hanya untuk menutupi tanah di sebelah pohon kelapa sawit, (Fajrih S, 2018). Jadi secara umum pelepah sawit tergolong sebagai salah satu limbah yang dihasilkan dalam proses budidaya kelapa sawit, sedangkan manfaat lain dari limbah pelepah sawit adalah untuk pakan ternak khususnya sapi (Widjaja E, et. al, 2012). Hanya saja pemanfaatan pelepah sawit sebagai pakan ternak, memiliki hambatan berupa rendahnya protein kasar yang hanya berkisar 2,11\% dan tingginya kandungan serat kasar yang mencapai 46,75\% (Murni et al., 2008). Pendapat lain menyatakan bahwa tingkat kecernaan pelepah sawit mencapai 45\% ( Efryantoni, 2012). Untuk mengatasi kekurangan pemanfaatan pelepah sawit sebagai pakan ternak, maka dilakukan inklusi secara maksimal berupa pengolahan melalui teknologi pakan salah satunya adalah fermentasi (Pranata RH, 2019; Mathius IW, 2008).

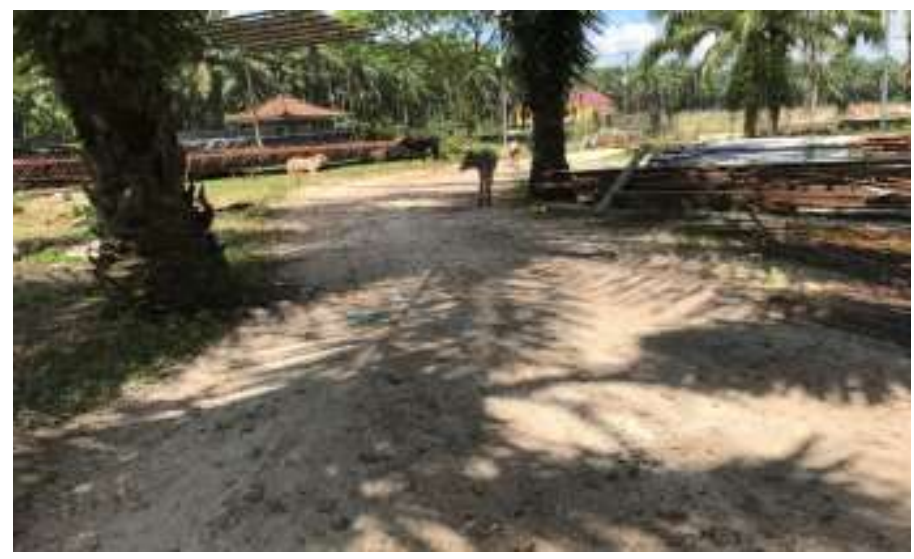

Gambar 2. Tanaman Sawit Dilahan Teknak Sapi Yayasan Merpati Putih 
Hasil survey lokasi, permasalahan yang ditemukan di Yayasan Merpati Putih, saat ini mengalami kesulitan dalam pemenuhan pakan ternak. Belum ada mesin yang dapat mencacah daun dan pelepah kelapa sawit untuk memenuhi pakan dalam jumlah banyak, menghabiskan waktu mencari dan memotong pakan. Untuk itu akan diusulkan program sosialisasi pengabdian masyarakat berupa mesin pencacah pelepah dan pelepah sawit yang sesuai untuk membantu permasalahan tersebut.Dari hasil diskusi dengan kelompok peternak di Desa Pancar Gading Kecamatan Tapung tersebut maka perlu solusi pemenuhan kebutuhan pakan ternak sapi dengan memanfaatkan limbah pelepah dan daun kelapa sawit maka perlu adanya mesin pencacah dengan kapasitas besar untuk mencacah pelepah dan daun kelapa sawit . yang mana pelepah dan daun kelapa sawit banyak tersedia di sekitar lokasi peternakan.

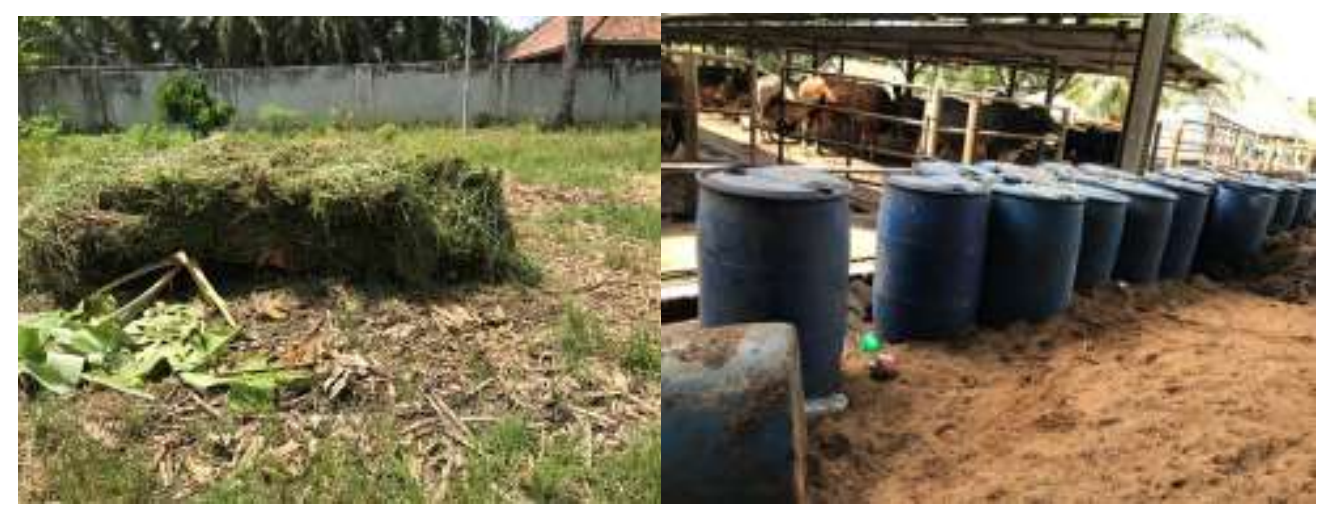

Gambar 3 Pakan Ternak dari Rumput Yang Dikumpulkan dan Dedak

Mesin yang akan dirancang dan dibuat untuk mengatasi permasalahan tersebut adalah mesin pencacah pelepah sawit dan perajang daun lontar yang digerakkan oleh mesin pembakaran. Selain itu, dengan adanya program ini diharapkan dapat terjalin hubungan yang saling menguntungkan antara mitra dengan tim IBM dari institusi pendidikan. Mitra akan mendapatkan teknologi tepat guna berupa mesin pencacah untuk pelepan dan daun lontar, sedangkan lembaga dapat mengaplikasikan iptek secara langsung dan mengaplikasikan ilmunya menjadi teknologi tepat guna. Secara rinci, target output yang diharapkan dalam IbM adalah target dan outcome untuk proses penghitungan pelepah dan daun sawit untuk pakan ternak, sehingga dapat membantu peternak dalam memanfaatkan pelepah dan daun tersebut sebagai pakan ternak secara efektif dan efisien.

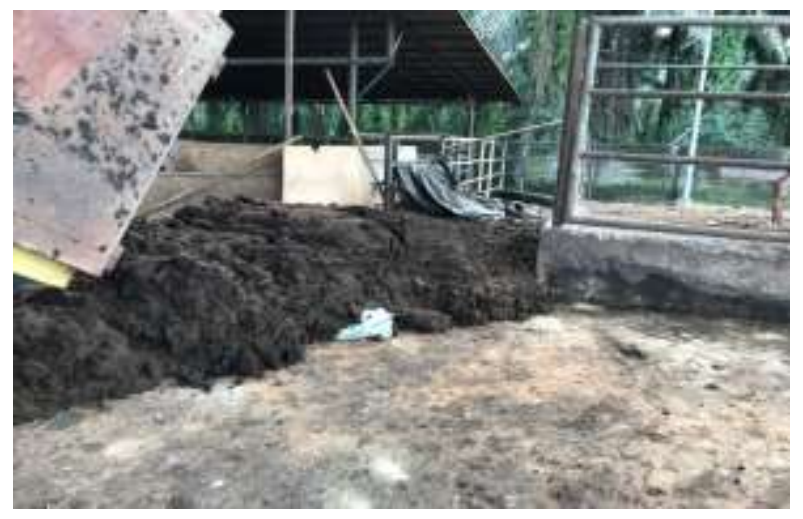

Gambar 4 Limbah Sapi untuk Pupuk Petani Sawit

Luaran yang diharapkan dari program ini adalah ternak menjadi lebih mudah dalam mengkonsumsi atau mencerna pakan ternak, mempermudah proses penghitungan pelepah sawit dan sampah bersama lainnya, dapat mencoba belajar mencari pakan ternak lain, dan menambah stok penyimpanan pakan ternak. Seluruh anggota kelompok tani wajib mengikuti pelatihan 
pengoperasian dan perawatan mesin perajang, agar mesin yang disediakan dapat digunakan oleh seluruh anggota yayasan merpati putih.

\section{METODE}

Untuk memberikan solusi bagi permasalahan mitra maka diberikan mesin pencacah daun dan pelepah kelapa sawit untuk dapat menghasilkan pakan ternak dalam jumlah banyak dalam waktu lebih sedikit atau waktu lebih efisien. Mesin yang diberikan adalah mesin dengan kapasitas besar dengan kemampuan mencacah 4000kg sampai dengan 5000kg per jam.

Berikut deskripsi mesin pengerak pencacah pakan ternak sapi yang akan diberikan ke mitra:

- Mesin awet atau bandel dalam istilah dimasyarakat

- Mudah dalam perawatannya

- Spare part mudah didapat

- Bahan bakar yang umum digunakan dan murah seperti solar

Sedangkan partisipasi mitra dalam pelaksanaan program pengabdian kepada masyarakat ini antara lain:

- Turut memberikan saran dan masukan dalam pengembangan mesin pencacah yang digunakan sehingga dapat menjadi alternatif pengembangan mesin pencacah berkelanjutan.

- Memberikan data tentang kemajuan perkembangan ternak sapi dan tinjauan secara ekonomis dan penilaian secara produktif terhadap dampak penggunaan mesin pencacah terhadap ketersediaan pakan ternak, dan pengaruhnya terhadap kemampuan menambah jumlah ternak yang dipelihara.

Tahapan-tahapan dalam menghasilkan solusi dalam kegiatan mitra saat ini ditunjukkan pada tabel 1

Tabel 1. Tahapan-Tahapan proses kegiatan

\begin{tabular}{|c|c|c|}
\hline Uraian & Metode & Pelaksana \\
\hline Keadaan saat ini & $\begin{array}{l}\text { Mitra masih memberi pakan dari rumput alam,Jerami } \\
\text { padi,limbah jagung secara tradisional }\end{array}$ & mitra \\
\hline $\begin{array}{l}\text { Solusi yang } \\
\text { ditawarkan }\end{array}$ & $\begin{array}{l}\text { Tim dan mitra berdiskusi mencari solusi agar pakan } \\
\text { ternak terpenuhi dengan cara mempermudah proses } \\
\text { pemenuhi pakan }\end{array}$ & Tim dan mitra \\
\hline Pemesanan alat & $\begin{array}{l}\text { Hasil kesepakatan tim dan mitra dipesan alat } \\
\text { pencacah pelepah dan daun sawit }\end{array}$ & Tim dan mitra \\
\hline Penyerahan mesin & $\begin{array}{l}\text { Tim menyerahkan mesin pencacah pelepah dan daun } \\
\text { kelepa sawit kepada mitra }\end{array}$ & Tim dan mitra \\
\hline $\begin{array}{l}\text { Pelatihan } \\
\text { pemakaian mesin }\end{array}$ & $\begin{array}{l}\text { Tim memberi pelatihan Bersama teknisi mesin } \\
\text { kepada mitra }\end{array}$ & $\begin{array}{l}\text { Tim ,tekhnisi, } \\
\text { mitra }\end{array}$ \\
\hline $\begin{array}{l}\text { Monitoring dan } \\
\text { evaluasi }\end{array}$ & $\begin{array}{l}\text { Monitoring dilakukan setelah dilatih bagiamana } \\
\text { mitra memakai dan memanfaatkan mesin pencacah }\end{array}$ & Tim dan mitra \\
\hline
\end{tabular}

Sedangkan prosedur kerja dalam kegiatan pengabdian kepada masyarakat ini dapat kami uraikan sebagai berikut :

- Membuat mesin pencacah

- Menyerahkan mesin pencacah ke Mitra

- Memberikan Pelatihan dalam pemakaian mesin pencacah

- Monitoring hasil kepada Mitra 


\section{HASIL DAN PEMBAHASAN}

Kegiatan diseminasi ini di lakukan di Desa Pancar Gading Kecamatan Tapung Kabupaten Kampar pada Yayasan Merpati Putih yang dihadiri oleh anggota Yayasan dan pemuka masyarakat di Desa Pancar Gading Kecamatan Tapung. Perkebunan kelapa sawit memiliki kemampuan untuk menyediakan pakan ternak baik dari limbah kebun maupun limbah industry, Hasil diskusi dengan mitra, mereka sangat terbantu dengan penyerahan mesin pencacah pelepah dan daun kelapa sawit yang banyak tersedia di sekitar mereka, sedangkan sapi yang jumlah besar sangat membutuhkan alat untuk mempercepat proses penyediaan pakan. Dengan adanya alat pencacah ini peternak tidak sulit lagi memenuhi kebutuhan pakan sapi dalam jumlah besar yang harus dipenuhi setiap hari. Yayasan merpati putih mengharapakan pembinaan lebih lanjut dari perguruan tinggi agar dapat nilai tambah dari usaha ternak sapi yang sudah ada.

Mesin pencacah dapat merubah ukuran partikel dan melunakkan tekstur bahan agar dikomsumsi ternak lebih efisien, dengan mesin pencacah maka sangat membantu percepatan pemenuhan jumlah pakan sapi setiap harinya. Menurut Pristiansyah dkk (2021), mesin pencacah yang dibuat dapat mengahasilkan cacahan sesuai dengan tuntutan yaitu, cacahan dengan dimensi $2 \mathrm{~cm}$ dan memberikan keuntungan dari segi efektifitas dan efisiensi waktu bagi petani dan peternak sapi dengan adanya mesin ini, karena proses sebelumnya masih manual.

Berdasarkan kebutuhan tersebut, mesin pencacah dibuat berdasarkan kebutuhan peternak sapi dan petani yaitu mesin awet atau bandel dalam istilah dimasyarakat, mudah dalam perawatannya, spare part mudah didapat dan bahan bakar yang umum digunakan dan murah seperti solar, maka dibuatlah mesin pencacah pakan sapi. Mesin pencacah dibuat memiliki 2 proses sekaligus yaitu menggiling bahan baku untuk memastikan tidak ada bahan padat atau pelumeran dan proses kegua yaitu mencincang bahan baku.

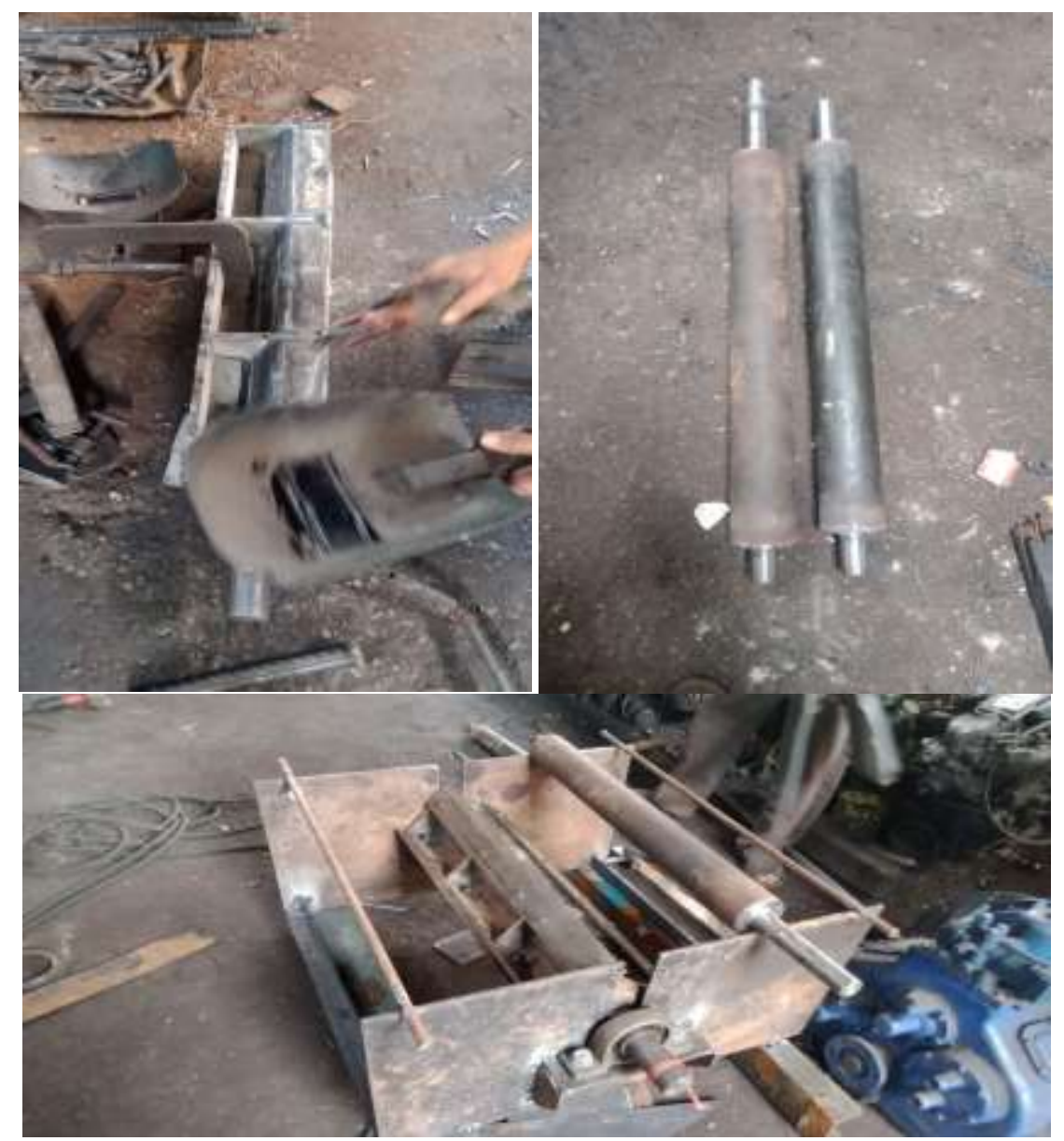

Gambar 5 Pembuatan Mesin Pencacah Pakan Ternak 
Penggerak pada mesin pencacah menggunakan mesin mitsubishi 100PS dengan konfigurasi 4 silinder dan kapasitas 3.800 cc berbahan bakar solar sehingga mesin pencacah dapat menghasilkan pakan ternak antara 4.000 sampai dengan $5.000 \mathrm{~kg}$ pakan per jam. Mesin pengerak mitsubishi 100ps adalah mesin yang awet dan mudah dalam perawatannya. Mencacah yang dibuat, didesain untuk mencacah daun kelapa sawit, rumput gajah dan sebagainya. Daun pelapah sawit dan rumput gajah memerlukan tenaga manusia yang banyak bila dilakukan pencacahannya secara manual dan tidak dapat langsung diberikan pada ternak bila tidak dicacah.

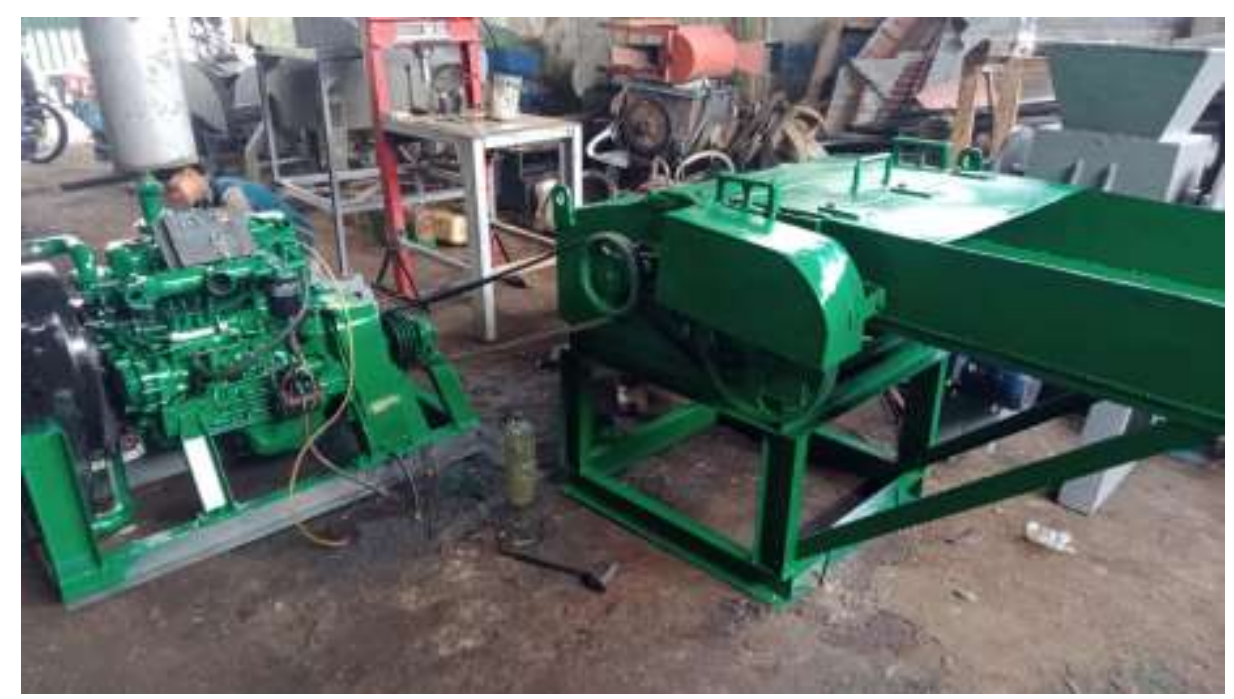

Gambar 6 Mesin Pencacah Pakan Ternak Bermesin Mitsubishi 100PS 3.800 cc

Hijauan pakan ternak alami semakin hari semakin berkurang karena berkurangnya luas lahan akibat alih fungsi dari padang pengembalaan menjadi tempat pemukiman atau perkebunan, sehingga waktu untuk mencari pakan hijauan semakin bertambah sementara jumlah ternak juga bertambah peternak mencari pakan cukup lama, 2-3 jam sehari untuk memperoleh rumput 30$40 \mathrm{~kg}$ rumput. Dilokasi kegiatan banyak ditanam kelapa sawit yang potensi limbahnya berupa pelepah dan daun kelapa sawit. Dari pabrik sawit menghasilkan tandan kosong,serabut buah.cangkang,solid dan bungkil inti sawit. Secara keseluruhan dapat dijadikan pakan ternak . Kandungan nutrisi daun dan pelepah kelapa sawit dari Gunawan dan Talib (2014) menjadi sumber acuan pengembangan pakan ternak berbasis pelepah kelapa sawit, yaitu bahan kering $(26.07 \%)$, protein kasar (3.07\%), lemak serat $(1.07 \%)$, serat kasar $(50.94 \%)$, total digestible nutrient (58.50\%), Kalsium (Ca) (0.96\%) dan Fosfor (p) (0.08\%). Sehingga dengan memanfaatkan limbah pasca panen pelepah kelapa sawit untuk diolah menjadi pakan ternak, bernilai gizi tinggi sebagai pengganti hijauan pakan ternak sapi hingga kadar 60\%, akan dapat meningkatkan bobot badan daging sapi ternak dan meningkatkan efisiensi pakan.

Berdasarkan data dari Direktorat Tanaman (Perkebunan Litbang Riau) 889.916 hektar sawit dikelola oleh BUMN sedangkan 812.439 hektar dikelola oleh swasta, sedangkan di kabupaten Kampar, 152.853 hektar dikelola oleh BUMN dan 127.211 hektar dikelola oleh swasta. Berdasarkan data tahun 2011 tersebut, pakan ternak yang bersumber dari daun sawit sangat berlimpah sehingga mesin pencacah yang diberikan akan tetap berfungsi karena sumber bahan mentah selalu tersedia.

\section{KESIMPULAN}

Berdasarkan kegiatan dan uraian diatas, penulis dapat menyimpulkan sebagai berikut : 
1. Mesin pencacah dapat membantu memperkecil daun dan pelepah sawit agar mudah di makan ternak sapi

2. Mesin pencacah dapat menghasilkan potongan daun dan pelepah kelapa sawit lebih kecil sehingga ternak mudah memakan dan peternak terbantu dapat dengan waktu lebih sedikit dalam menyediakan pakan karena selama ini masih manual.

\section{DAFTAR PUSTAKA}

Efryantoni (2012). Pola Pengembangan Sistem Integrasi Kelapa Sawit - Sapi Sebagai Penjamin Ketersediaan Pakan Ternak. Bengkulu: Fakultas Pertanian Universitas Bengkulu.

Fajrih. S. (2018). Pelepah Kelapa Sawit - Pakan Alternatif Ternak Sapi. Fakultas Peternakan Universitas Jambi

Gunawan dan Talib, C. (2014). Potensi Pengembangan Bioindustri Dalam Sistem Integrasi Sapi Sawit. WARTAZOA Vol 24. No 2. Hal 67-74.

Inayati, A. (2012). Pelepah Sawit Bisa Dijadikan Pakan ternak Sapi

Mathius, I. W. (2008). Pengembangan Sapi Potong berbasis Industri Kelapa Sawit. Pengembangan Inovasi Pertanian. Hal: 206 -224

Murni, R., Suparjo, Akmal, B. L. \& Ginting. (2008). Buku Ajar Teknologi Pemanfaatan Limbah untuk Pakan. Laboratorium Makanan Ternak. Jambi: Fakultas Peternakan. Universitas Jambi.

Pranata, RH., Arico, Z. (2019). Pemanfaatan Limbah Kebun Pelepah Kelapa Sawit (Elaeis guinensis Jacq) Sebagai Alternatif Pakan Ternak Bernilai Gizi Tinggi. Jurnal Biologica Samudra 1 (1): 17-24.

Pristiansyah , Hasdiansah , Sugiyarto. (2021). IBM Iptek Bagi Masyarakat Mesin Pencacah Pelepah Dan Daun Kelapa Sawit Untuk Pakan Sapi Di Desa Sempan. Dulang ,Jurnal Pengabdian Masyarakat,vol.1.no.1.

Siswati, L., Ariyanto, A., Lestari, S. U., Setiawan, D., \& Yandra, A. (2021). Manfaatkan Urin Sapi Menjadi Pupuk Organik Cair di Desa Teluk Jering Kecamatan Tambang. Community Empowerment, 6(2), 291-296.

Widjaja, E., dan B. N. Utomo. (2012). Pemanfaatan limbah kelapa sawit solid sebagai pakan tambahan ternak ruminansia di Kalimantan Tengah. Prosiding Seminar Nasional Peternakan dan Veteriner. Bogor, 17-18 September 2001. 